\title{
A Pre-Eclampsia Guidence Program in the Community Based on the Pre-Eclampsia Community Guide
}

\author{
Rahmawati $^{1}$, Woro Tri Utami ${ }^{2}$, Detyy Siti Nurdiati ${ }^{3}$, Abdul Muhith ${ }^{4}$ \\ \{andaru.al.vaya.@gmail.com ${ }^{1}$,woroarwani@gmail.com², dnurdiati@yahoo.com ${ }^{3}$, \\ abdulmuhith@unusa.ac.id $\left.{ }^{4}\right\}$
}

\begin{abstract}
Nursing Department, Academi Health Rajakwesi Bojonegoro ${ }^{1}$, Midwife Department, Academi Midwife Wira Husada Nusantara Malang ${ }^{2}$, University of Gajah Mada Yogjakarta ${ }^{3}$, Nursing Department, University of Nahdlatul Ulama Surabaya ${ }^{4}$
\end{abstract}

\begin{abstract}
Preeclampsia is a major cause of maternal mortality, Bojonegoro is one area which has an MMR of fluctuating over the last 3 years. Nonetheless, there is no single program is held to address the issue of preeclampsia. To Analyze the effectiveness of the PRECOG program on the management of preeclampsia in Bojonegoro District. The research method is quantitative are represented by The Dander Health Center consisting of 9 villages and The Kepoh Baru 13 villages. The intervention was given to Dander health center by implementing the PRECOG program which consisted of guidance on early detection and recommendations through cadre training, and manipulation of maternity services according to PRECOG, while Kepoh Baru health center was a comparison. The sample are all pregnant women in amount 220 people in Dander and 100 people in Kepoh Baru with Total Sampling Technique. The effectiveness of PRECOG to handle pre eclampsia is measured by comparing risk factor screening, Detection and recommendation of two districts. There are significant differences in risk factor screening. The PRECOG guide shows that $68.75 \%$ with Diastolic BP of $80-89 \mathrm{mmHg}$ as a risk factor developing into a preeclampsia while without the PRECOG, it is not a risk factor, even though the diastolic BP is $80-89 \mathrm{mmHg}$ by $50 \%$. The recommendation measured by Chisquare test with $\alpha 5 \%$ obtained sig. 1.00 , which means there is no difference in recommendation. Early detection and accuracy of the screening results and recommendations are the most important thing in vigilance pre eclampsia to suppress MMR due to pre eclampsia.
\end{abstract}

Keyword: precog, maternal mortality, screening, detection

\section{Introduction}

Maternal Mortality Rate (MMR) is an indicator for women's welfare and development success for a country. The Millennium Development Goal's 5th agenda is to achieve maternal health with a target of reducing MMR to $3 / 4$ the risk of maternal deaths of 102/100 thousand live births by 2015 [1]. Preeclampsia is one of the major causes of maternal and fetal mortality and morbidity. $80 \%$ of the causes of maternal death are bleeding, preeclampsia and infection. Based on Indonesia Demographic and Health Survey (SDKI) in 2012, MMR in Indonesia amounted to 
359 / 100,000 live births, still high compared to 2014 achievement target of 118 / 100.000 live birth. According to reports of maternal deaths in East Java during 2009-2011 MMR has increased, although in 2012 MMR 97.43 / 100,000 live births were below the MDG's target, but the main cause of MMR in East Java was preeclampsia, which amounted to $34.88 \%$ [2]. In Bojonegoro MMR is a key priority in the mapping of health problems in 2012. unstable MMR feared would tend to increase and lead to potential problems middle Term Development Plan of Bojonegoro targeting to MMR in 2015 was 88, 05 / 100,000 live births. Achievements MMR Bojonegoro District last 3 years tend to fluctuate. The MMR year of 95.5 / 100,000 live births, rising sharply in 2013 of 108.5 / 100,000 live births and then declining sharply in 2014 ie 65.75 / 100,000 live births. The fluctuating MMR condition illustrates the inconsistency of MMR treatment, which in the last 3 years is dominated by preeclampsia.

Preeclampsia is a syndrome characterized by elevated blood pressure and proteinuria that appear in secondtrimester pregnancies that always recover in the postnatal period [3]. Preeclampsia is influenced by several factors primigravidae or $>10$ years since the last birth, her first pregnancy with a new partner, a history of preeclampsia earlier, a family history of preeclampsia, pregnancy, certain medical conditions, proteinuria, age $>40$ years, obesity and fertility in Vivo. Complications of preeclampsia include the occurrence of placental abruption, HELLP syndrome, brain hemorrhage, pulmonary edema, necrosis of the liver, kidney disorders, hemolysis, so that preeclampsia lead to a high mortality rate for both mother and fetus [4].

Government programs in reducing maternal mortality include safe motherhood, maternal love movements, increasing access to the poor and perinatal maternal audits $[5,8,9,10]$. The treatment of preeclampsia in Indonesia is more focused on the clinical setting, while the majority of deaths from preeclampsia are associated with substandard care, namely failure to identify and act on known risk factors for examination and failure to recognize and act appropriately on signs and symptoms from a 20 -week pregnancy. In $80 \%$ of maternal deaths and $65 \%$ of fetal deaths, improper care and handling contribute significantly [6].

The Pre Eclampsi Community Guideline (PRECOG) is a framework for antenatal care in the community that have been successfully developed in the UK since 2004 in the form of guidelines for screening and early detection of preeclampsia in society and the guidelines for referral of the public to step up care. This guide contains several things, namely: 1) a simple assessment in pregnant women at the time of examination at risk to develop into preeclampsia, 2) Factors associated with preeclampsia who require specialist referral early in pregnancy, 3) community assessment systematic indication The incidence of preeclampsia from a 20-week pregnancy. Given that maternal mortality due to preeclampsia is associated with delays in recognizing and inaccurate actions taken, it not only requires a clinical order, but also community participation, because the development of risk factors and signs of symptoms in pregnant women to become preeclampsy should be well recognized by the community, so that people can take appropriate action to avoid delay in the treatment of preeclampsia, where the expected participation has been arranged in the PRECOG guidelines [6]. Comparing screening, detection and preeclampsia recommendations based on The Preeclampsi Community Guideline (PRECOG) in Bojonegoro District 2016.

\section{Materials and Methods}

The type of research is quasy experiment, with post test only with control group design.Population and sample were pregnant mother and village midwife in Kepoh Baru sub district as control group and Dander sub district as intervention group year 2016. The population and sample of this study were all pregnant women who had been recorded in the data of village midwives with 220 pregnant women at Dander Health Center and 100 pregnant women at the Kepoh Baru Health Center with Total Sampling technique that both the intervention group and the comparison group all pregnant women were taken as sample. This research will be carried out with manipulating preeclampsi guidence program by community guideline (PRECOG) in intervention group and control group as a comparison. The variables in this study were screening risk factors for preeclampsia, early preeclampsia detection, recommendations for follow-up screening risk factors and recommendations for follow-up detection of preeclampsia. The indicator of preeclampsia screening is the ability of the screening guide in screening risk factors that can develop into preeclampsia. The indicator of early preeclampsia detection is pregnant women who experience signs and symptoms of preeclampsia after 20 weeks' gestation. The indicator of recommendations for follow-up screening risk factors and detection of preeclampsia is the suitability of recommendations for followup cases found with the PRECOG guidelines.

The steps to achieve the intervention stage of the PRECOG program are survey of maternal health services in Kepoh Baru Health Center and Dander Health Center, Bojonegoro District, survey of maternal health services in ponkesdes there are basic health services located in villages handled by midwives and nurses or polindes that gives maternal services located in the village managed by village midwives in Kepoh Baru sub district and Dander Sub-districts,study secondary data of preeclampsia events in ponkesdes or polindes and Kepoh Baru and Dander Health Center, provide education and training to village midwives about PRECOG programs, manipulate the standard of health services of pregnant women according to PRECOG program, arranging the provision of 
maternal health services in the community by the village midwife or by the health center in accordance with the PRECOG Program. The steps of achieving early detection indicators and pregnancy preeclamps case handling in the community are by choosing health cadres in each village in Dander District, empowering cadres to record all pregnant women in each village in Dander District, data of pregnant women submitted to village midwives respectively as monitoring, provide counseling to all pregnant women in each village in Dander District about the health of pregnant women, monitoring the development of pregnant women's health and Implement PRECOG program in pregnant women detected preeclampsy carried out by village midwives, and at the end of the year counted the number of pregnant women detected preeklamsi and handling either at the Kepoh Baru or Dander health center

Data processing was carried out descriptively-quantitative, where the screening and detection of preeclampsia of pregnant women was carried out after PRECOG training while the preeclamptic treatment was measured from the compliance of recommendation of village midwife and puskesmas on the severity of preeclampsia by using the PRECOG program reference both intervention and control group. In the preeclampsia screening process a descriptive analysis will be conducted to compare preeclamptic risk factors at Dander health Center (PRECOG) with Kepohbaru Health Center (control). The preeclampsia detection is analyzed descriptively to compare the percentage of preeclampsia occurrence and the underlying risk factors developed into preeclampsia. Recommended follow-up screening and detection of preeclampsia compared with using Chi Square test, because comparing in 2 free groups and the scale of the data used was nominal

All the respondents signed the informed consent agreement which was conducted voluntarily. This research was approved by the Health Research and Community Service Ethics Committee at Rajekwesi Heatlh Academy. The study also obtained the permission of two community health center where the research was conduct.

\section{Results}

Table 1. The Different of Risk Factors Screening of Preeclampsi at Dander and Kepoh Baru Health Center

\begin{tabular}{|c|c|}
\hline Dander Health Center & Kepoh Baru Health Center \\
\hline Main Risk Factors & Predisposition Factors \\
\hline 1. Gemelly & 1. Primigravida, primi partnership \\
\hline $\begin{array}{l}\text { 2. Medical Condition : } \\
\text { a. Diastol } \mathrm{BP} \geq 90 \mathrm{mmHg}\end{array}$ & $\begin{array}{l}\text { 2. Hyperplasentosition conditions : } \\
\text { a. Molahydatidose }\end{array}$ \\
\hline b. Kidney disease or previous protein & b. Multiple Pregnancy \\
\hline urine level +1 in more than 1 time & c. DM \\
\hline measurement & d. Hidroipfetalis \\
\hline c. DM & e. Big baby \\
\hline d. Antifosfolipid antibody & 3. Family preeclampsi history \\
\hline 3. Previous Preeclampsia history & $\begin{array}{l}\text { 4. Kidney Disease and Hypertension } \\
\text { before pregnancy }\end{array}$ \\
\hline Additional Risk Factors & 5. Obesity dan Metabolic Syndrome \\
\hline 1. Primigravida & 6. Extrime Age $(<20$ years and \\
\hline 2. Pregnancy Distance to prevoius birth $>10$ years & $>40$ years \\
\hline \multicolumn{2}{|l|}{ 3. Age $\geq 40$ years } \\
\hline \multicolumn{2}{|l|}{ 4. Family preeclampsi history } \\
\hline \multicolumn{2}{|l|}{$5 . \mathrm{IMT} \geq 35$} \\
\hline \multicolumn{2}{|l|}{ 6. Diastole $\mathrm{BP} \geq 80-<90 \mathrm{mmHg}$} \\
\hline $\begin{array}{l}\text { 7. Urine Protein level }+1 \text { in more than } 1 \\
\text { time measurement }\end{array}$ & \\
\hline
\end{tabular}

Screening is an activity to find the risk factors of pregnant women who can develop into preeclampsia since the first meeting of pregnant women to implement ANC. Table 1 illustrates the guidelines for preeclampsia screening at the Dander Community Health Center as intervention group (PRECOG) while the Kepohbaru 
Community Health Center as a control. Table 1 clearly illustrates the differences in screening between the two. Most screening guidelines are the same, but there are fundamental and sensitive differences that can develop into preeclampsia, namely, that with PRECOG, birth distance factors> 10 years, diastolic blood pressure, BMI, and urine protein are screened from the beginning of pregnancy, whereas without PRECOG it is not part of screening.

Table 2. The Recommendation of Risk Factors Screening Guide of Preeclampsi at Dander and Kepoh Baru Health Center

\begin{tabular}{|c|c|c|c|}
\hline \multicolumn{2}{|c|}{ Dander Health Center } & \multicolumn{2}{|c|}{ Kepoh Baru Health Center } \\
\hline Risk Factors & Recommendations & Risk Factors & Recommendations \\
\hline One Main Risk Factor or 2 & Refer to a hospital with & Predisposituon Factors & Supervision \\
\hline Additional Factors & adequate facilities for & & \\
\hline & the ANC & & \\
\hline \multirow[t]{6}{*}{ One Additional Risk Factor } & Doing The ANC : & & \\
\hline & a. Once every three weeks & & \\
\hline & at $20-32$ weeks & & \\
\hline & Gestation & & \\
\hline & b. Once every two weeks & & \\
\hline & at $>32$ weeks gestation & & \\
\hline Without Risk Factors & The ANC standard & & \\
\hline
\end{tabular}

Table 2 shows that recommendations for risk factors in the PRECOG guidelines at Dander Community Health Center are based on the risk factors found in pregnant women since the first visit, so an early vigilance system has been prepared to undergo a systematic range of pregnancies, while in Kepohbaru health centers non-intervention, recommendations on predisposing factors are supervision, without any systematic guidance. The main risk factors are risk factors that have a direct effect on the occurrence of preeclampsia, therefore in PRECOG with these risk factors, pregnant women need to be referred to hospitals with adequate facilities for ANC. Whereas with 1 additional risk factor that can develop into preeclampsia, it needs supervision in ANC with different intervals and relatively more often than pregnant women without risk factors.

Table 3. The Detection Guide of Preeclampsi at Dander and Kepoh Baru Health Center

\begin{tabular}{|c|c|}
\hline Dander Health Center & Kepoh Baru Health Center \\
\hline Preeclampsi Signs & MAP (Mean Arterial Pressure) \\
\hline a. Hipertension & a. $(2$ diastole $\mathrm{BP}+1$ sistole $\mathrm{BP}) / 3$ \\
\hline b. Protein urine & b. Risk of preeclampsi if MAP $\geq 90 \mathrm{mmHg}$ \\
\hline Preeclampsi Symptoms : & ROT (Role Over Test) \\
\hline a. Headache and or visual disorder & a. Supine Diastole BP position - fTilt Diastol BP position \\
\hline b. Heartburn and or nausea and vomitus & on the same arm. Risk of preeclampsi if the result \\
\hline \multirow[t]{3}{*}{ c. Slow fetal movement or slow growing fetus } & $\geq 20 \mathrm{mmHg}$ \\
\hline & BMI \\
\hline & a. If $\mathrm{BMI} \geq 29$ \\
\hline
\end{tabular}

Table 3 describes the guidelines for detection of preeclampsia at the Dander Health Center (PRECOG) and Kepohbaru Health Center (Control). The fundamental difference from the guidelines is that with PRECOG, preeclampsia was detected based on hypertension, urine protein and underlying symptoms, while controls detected preeclampsia based on diastolic blood pressure and BMI. Especially for BMI, in PRECOG, BMI is a risk factor 
that can develop into preeclampsia. Based on the results of the interview, although in the control group there were no urine protein conditions as the detection of preeclampsia, but based on experience, when pregnant women experience urine protein + , the preeclampsia will be detected.

Table 4. Result of Recording and Reporting of Pregnant Women Screening at Dander and Kepohbaru Health Center

\begin{tabular}{|c|c|c|c|c|}
\hline \multirow[t]{2}{*}{ Risk Factors } & \multicolumn{2}{|c|}{ Dander Health Center } & \multicolumn{2}{|c|}{ Kepoh Baru Health Center } \\
\hline & Amount & $\%$ & Amount & $\%$ \\
\hline \multicolumn{5}{|l|}{ Pregnancy } \\
\hline Primi Gravida & 124 & 56.4 & 70 & 70 \\
\hline Multi gravid & 96 & 43.6 & 30 & 30 \\
\hline \multicolumn{5}{|l|}{ Preeclampsi history } \\
\hline Yes & 1 & 0.5 & 0 & 0 \\
\hline No & 119 & 99.5 & 100 & 100 \\
\hline \multicolumn{5}{|l|}{ History of Kidney Disease } \\
\hline Yes & 0 & 0 & 0 & 0 \\
\hline No & 220 & 100 & 100 & 100 \\
\hline \multicolumn{5}{|l|}{ History of DM } \\
\hline Yes & 0 & 0 & 0 & 0 \\
\hline No & 100 & 100 & 100 & 100 \\
\hline \multicolumn{5}{|l|}{ History of hioertension } \\
\hline Yes & 1 & 0.5 & 11 & 11 \\
\hline No & 119 & 95.5 & 89 & 89 \\
\hline \multicolumn{5}{|l|}{ Pregnancy Distance } \\
\hline$<10$ years & 80 & 36.3 & 30 & 30 \\
\hline$\geq 10$ years & 18 & 8 & 0 & 0 \\
\hline Multiple Pregnancy & 0 & 0 & 0 & 0 \\
\hline Urine Protein + & 0 & 0 & 0 & 0 \\
\hline \multicolumn{5}{|l|}{ BMI } \\
\hline$<35$ & 217 & 98.6 & 100 & 100 \\
\hline$\geq 35$ & 3 & 1.4 & 0 & 0 \\
\hline \multicolumn{5}{|l|}{ Diastole BP } \\
\hline$<80 \mathrm{mmHg}$ & 113 & 51.4 & 57 & 57 \\
\hline $80-89 \mathrm{mmHg}$ & 96 & 43.4 & 38 & 38 \\
\hline$\geq 90 \mathrm{mmHg}$ & 11 & 5 & 5 & 5 \\
\hline
\end{tabular}

Table 4 illustrates that the risk factors of pregnant women found in Dander Puskesmas are primigravida $(56.4 \%)$, preeclampsia history $(0.5 \%)$, history of hypertension $(0.5 \%)$, pregnancy spacing of more than 10 years $(8 \%)$, IMT $>35$ (1.4\%), diastolic blood pressure $80-89 \mathrm{mmHg}(43.4 \%)$ and $>90 \mathrm{mmHg}(5 \%)$. Table 2 illustrates that risk factors that can develop into preeclampsia in Kepohbaru Health Center are primigravida (70\%), history of hypertension (11\%), diastole blood pressure $80-89 \mathrm{mmHg} \quad(38 \%)$ and $>90 \mathrm{mmHg}(5 \%)$. Table 3 illustrates 
that the follow-up recommendations carried out by the Dander health center as a PRECOG intervention $97.7 \%$ are appropriate, whereas Dander Puskeemas as 95\% controls are not appropriate.

Table 5. Recommended follow-up results of screening of Dander and Kepohbaru Health Center

\begin{tabular}{lcccccc}
\hline Community Health Center & \multicolumn{3}{c}{ Follow Up } & \multicolumn{2}{c}{ Total } \\
& \multicolumn{2}{c}{ Appropriate } & Not Appropriate & & \\
\hline & $\mathrm{N}$ & $\%$ & $\mathrm{~N}$ & $\%$ & $\mathrm{~N}$ & $\%$ \\
Dander (PRECOG) & 215 & 97.7 & 5 & 2.3 & 220 & 100 \\
Kepohbaru (control) & 5 & 5 & 95 & 95 & 100 & 100 \\
\hline
\end{tabular}

Based on the analysis using Chisquare test using significance level $\alpha 5 \%$ obtained sig results. 0.00 , which means that there are differences in recommended follow-up screening results conducted at Dander Health Center (PRECOG) and Kepohbaru Health Center (control). Considering the level of compliance at Dander health center higher, it can be concluded that the recommendation of follow-up of Dander health center screening results (PRECOG) is more detailed and more vigilant than Kepohbaru (control). Detection of Preeclampsia is an activity to find pregnant women with preeclampsia after 20 weeks' gestation until the mother completes the puerperium. Table 6 explains that preeclamptic detection is performed on the condition of hypertension, urine protein and symptoms. At Dander Health Center from 16 mothers detected preeclampsia, 9 mothers (4.09\%) with hypertension without urine protein, 7 (3.18) mothers found hypertension with urine protein while in Kepohbaru Health Center, from 10 mothers, 50\% each detected hypertension with urine protein and hypertension without urine protein. In the case of preeclampsia was not found on the basis of symptoms of preeclampsia $(0 \%)$. In both groups, there were no mothers who detected preeclampsia based on the symptoms of preeclampsia but based on the condition of hypertension and urine protein. The advantages of PRECOG are being able to detect preeclampsia in women who do not even have hypertension and urine proteins, but experience symptoms of hypertension such as visual disturbances and / or headaches, heartburn and or vomiting, slow fetal movements or less developed fetuses.

Table 6. Detection Result of Preeclampsi at Dander and Kepohbaru Health Center

\begin{tabular}{|c|c|c|c|c|c|c|c|c|c|c|}
\hline \multirow{3}{*}{$\begin{array}{c}\text { Community Health } \\
\text { Center }\end{array}$} & \multicolumn{8}{|c|}{ Preeclamption Detection } & \multirow{2}{*}{\multicolumn{2}{|c|}{ Total }} \\
\hline & \multicolumn{2}{|c|}{$\begin{array}{c}\text { Hipertention } \\
\text { with protein } \\
\text { urine }+\end{array}$} & \multicolumn{2}{|c|}{$\begin{array}{l}\text { Hipertention } \\
\text { without } \\
\text { protein urine }\end{array}$} & \multicolumn{2}{|c|}{ Symptoms } & \multicolumn{2}{|c|}{$\begin{array}{c}\text { Not } \\
\text { Preclampsi }\end{array}$} & & \\
\hline & $\mathrm{N}$ & $\%$ & $\mathrm{~N}$ & $\%$ & $\mathrm{~N}$ & $\%$ & $\mathrm{n}$ & $\%$ & $\mathrm{n}$ & $\%$ \\
\hline Dander (PRECOG) & 7 & 3.18 & 9 & 4.09 & 0 & 0 & 204 & 92.7 & 220 & 100 \\
\hline $\begin{array}{c}\text { Kepohbaru } \\
\text { (Control) }\end{array}$ & 5 & 5 & 5 & 5 & 0 & 0 & 90 & 90 & 100 & 100 \\
\hline
\end{tabular}

Table 7 illustrates that the underlying risk factors developed into preeclampsia in Pandemic Dander are primi gravida $(6.25 \%)$, age $>40$ years $(31.25 \%)$, history of preeclampsia $(6.25 \%)$, history of hypertension $(12.5 \%)$, Diastolic blood pressure $80-89 \mathrm{mmHg}(68.75 \%)$ and diastolic blood pressure $>90 \mathrm{mmHg}(31.25 \%)$. The underlying risk factors developed into preeclampsia in Kepohbaru Health Center were primigravida (20\%), age $<20$ years $(10 \%)$, history of hypertension (30\%), diastole blood pressure $80-89 \mathrm{mmHg}(50 \%)$, and blood pressure $>$ $90 \mathrm{MmHg}(40 \%)$. The interesting thing that was found was that in Kepohbaru Health Center 50\% blood pressure risk factor 80-89 $\mathrm{mmHg}$ developed into preeclampsia, but based on table 3, it did not include the risk factors considered to develop into preeclampation. Table 8 explains that at the Dander Health Center, from 16 mothers who detected preeclampsia, 15 mothers $(93.75 \%)$ recommended according to preeclampsia motherhood and 1 mother $(6.25 \%)$ are not appropriate. While in Kepohbaru health center all (100\%) of mothers with preeclampsia were recommended in accordance with preeclampsia mother's condition. The conformity of the recommendations in this study in general is a referral program for mothers who have detected preeclampsia 
Table 7. Distribution of Risk Factors Underlying Preeclampsia at Dander and Kepohbaru Health Center

\begin{tabular}{|c|c|c|c|c|c|c|}
\hline \multirow[t]{2}{*}{ No } & \multicolumn{3}{|c|}{ Dander Health Center } & \multicolumn{3}{|c|}{ Kepohbaru Health Center } \\
\hline & Risk Factor & $\mathrm{f}$ & $\%$ & Risk Factor & $\mathrm{F}$ & $\%$ \\
\hline 1 & First Pregnancy & 1 & 6,25 & First Pregnancy & 2 & 20 \\
\hline 2 & Age $\geq 40$ years & 5 & 31,25 & Age $<20$ years & 1 & 10 \\
\hline 2 & History of Preeclampsia & 1 & 6,25 & History of Preeclampsia & 0 & 0 \\
\hline 3 & History of Kidney Diease & 0 & 0 & History of Kidney Diease & 0 & 0 \\
\hline 4 & History of DM & 0 & 0 & History of DM & 0 & 0 \\
\hline 5 & History of Hipertension & 2 & 12,5 & History of Hipertension & 3 & 30 \\
\hline 6 & $\geq 10$ years since last baby & 0 & 0 & $\geq 10$ years since last baby & 0 & 0 \\
\hline 7 & Multiple Pregnancy & 0 & 0 & Multiple Pregnancy & 0 & 0 \\
\hline 8 & Protein Urine + & 0 & 0 & Protein Urine + & 0 & 0 \\
\hline 9 & $\mathrm{IMT} \geq 35$ & 0 & 0 & IMT & 0 & 0 \\
\hline 10 & BP Diastole & & & BP Diastole & & \\
\hline & $80-89 \mathrm{mmHg}$ & 11 & 68,75 & $80-89 \mathrm{mmHg}$ & 5 & 50 \\
\hline & $\geq 90 \mathrm{mmHg}$ & 5 & 31,25 & $\geq 90 \mathrm{mmHg}$ & 4 & 40 \\
\hline
\end{tabular}

Based on the analysis using Chisquare test using significance level $\alpha 5 \%$ obtained sig results. 1.00 , which means there is no difference in recommendation of follow-up of preeclampsion detection done at Dander Health Center (PRECOG) and Kepohbaru Health Center (control). It can be concluded that the recommendation of follow up of preeclampsion detection result both at Dander Health Center (PRECOG) and Kepohbaru Health Center (Control) has been in accordance with that.

Table 8. Recommended Follow-up Detection of Preeclampsia at Dander and Kepohbaru Health Center

\begin{tabular}{|c|c|c|c|c|c|c|}
\hline \multirow[t]{3}{*}{ Community Health center } & \multicolumn{4}{|c|}{ Follow Up } & \multicolumn{2}{|c|}{ Total } \\
\hline & \multicolumn{2}{|c|}{ Appropriate } & \multicolumn{2}{|c|}{$\begin{array}{c}\text { Not } \\
\text { Appropriate }\end{array}$} & \multirow[b]{2}{*}{$\mathrm{n}$} & \multirow[b]{2}{*}{$\%$} \\
\hline & $\mathrm{N}$ & $\%$ & $\mathrm{~N}$ & $\%$ & & \\
\hline Dander (PRECOG) & 15 & 93,75 & 1 & 6,25 & 16 & 100 \\
\hline $\begin{array}{l}\text { Kepohbaru } \\
\text { (Control) }\end{array}$ & 10 & 100 & 0 & 0 & 10 & 100 \\
\hline
\end{tabular}

\section{Discussions}

Screening for preeclampsia is an activity to find risk factors for preeclampsia since the first visit of pregnant women. Screening is differentiated by PRECOG and control, where PRECOG is implemented at Dander Community Health Center and controls at Kepohbaru. Differences in risk factors with non PRECOG is that PRECOG risk factors include major risk factors that consists of multiple pregnancy, underlying conditions (diastolic blood pressure $>90 \mathrm{mmHg}$, or previously had kidney disease proteinurine +1 on more than 1 time 
measurement, DM, antiphospholipid Antibody) and previous preeclamptic history. Additional risk factors include primigravida, birth spacing $>10$ years, age $>40$ years, BMI $>35$, family history of preeclampsia, diastolic blood pressure $>80 \mathrm{mmHg}$ and $<90 \mathrm{mmHg}$, urine protein + in more than 1x measurement. The risk factor in controls (Non PRECOG) is referred to as predisposing factors include primigravidae, primi partnernitas, conditions hyperplasentosisi (molahydatidosa, pregnancy multiple, DM, Hidroipfetalis, big baby), family history of preeclampsia, kidney disease and hypertension before pregnancy, obesity and metabolic syndrome, Extreme age $(<20$ years and $>40$ years $)$.

The risk factors show that there are some differences: BMI, diastolic blood pressure $>80 \mathrm{mmHg}$ and $<90$ $\mathrm{mmHg}$, urine protein + in more than $1 \mathrm{x}$ measurement. These three factors are at risk of developing into preeclampsia. Physiologically, the pregnant mothers maternal blood volume began to increase at the beginning of pregnancy as a result of changes osmoregulasi and renin- angiotensin system, causing retention of sodium and an increase in total body water to $8.5 \mathrm{~L}$ and diluted blood called hemodilution. This phase occurs at 16-32 weeks' gestation. In its time, blood volume increased to $45 \%$ where the volume of red blood cells only increased to $30 \%$. This increased difference can lead to "physiological anemia" in pregnancy with an average hemoglobin of $11.6 \mathrm{~g}$ / $\mathrm{dl}$ and 35.5\% hematocrit (Birnbach, 2009). At this time the blood vessels dilate and along with hemodilution, causing maternal blood pressure tends to decrease 100-110 / 60-70 mmHg. Blood pressure showed more than it was shown that under conditions of blood vessels dilated and hemodilution, the heart is still working too hard at risk of hypertension, which causes the occurrence of hypertension in pregnancy preeclampsia [7]. Table 7 shows that the majority of risk factors experienced by pregnant women at Dander and Kepohbaru health centers are primigravidas and diastolic blood pressure of $80-89 \mathrm{mmHg}$, namely Dander Health Center show primigravidae by $56.4 \%$, and a diastolic blood pressure of $80-89 \mathrm{mmHg} 43.3 \%$, While Kepohbaru Health Center showed $70 \%$ primigravida, and diastole blood pressure $80-89 \mathrm{mmHg} 38 \%$. Given the high number of risk factors that may escape attention, causing pregnant women to be at risk from the midwife supervision.

The follow-up recommendations of screening results in PRECOG are tailored to risk factors. Pregnant women with 1 major risk factor or 2 additional risk factors should then be referred to hospitals that have adequate health care facilities to perform ANC. While the mother who has 1 additional factor then ANC bias carried out once a month until the age of 19 weeks of pregnancy. Age 20-32 weeks ANC is done every 3 weeks while gestational age $>32$ weeks is held every 2 weeks. Standard ANC is implemented if the mother does not have risk factors. On Control (non PRECOG) is not specified in the follow-up of the screening discovery. In the absence of clear guidelines in this follow-up, there is a risk of unequal treatment of risk factors for pregnant women and can lead to neglect which may lead to late detection of preeclampsia. Based on Table 4 explains that the PHC Dander (PRECOG) of 220 pregnant women who are at risk of 215 (97.7\%) of pregnant women get recommendations for further action in accordance with the risk factors, while Kepohbaru (control) of 100 pregnant women at risk amounted to $95(95 \%)$ Pregnant women do not get the appropriate recommendations.

Detection of preeclampsia based PRECOG preeclampsia include hypertension, urinary protein and symptoms of preeclampsia (headache or visual disturbances, heartburn or vomiting initially, your baby's movements slow and slow growing fetus), while in the control (non PRECOG), detection of preeclampsia based MAP (2 diastole +1 systole / 3 , if the result is $>90 \mathrm{mmHg}$ then the risk of pre-eclampsia), ROT (diastole in the supine positiondiastole tilted position on the same arm. the risk of preeclampsia if results>20mmHg), BMI> 29 at risk Preeclampsia. If noted, detection of preeclampsia in the control emphasizes the diastolic blood pressure. Interviews showed that detection of preeclampsia included triad of symptoms, namely hypertension, urine protein and oedem. In PRECOG, in addition to conditions of hypertension and urine protein, preeclampsia is detected based on existing symptoms. Preeclampsia is a pregnancy poisoning that occurs from the age of 20 weeks to after delivery (NICE, 2011) During childbirth, pregnant women who during preeclampsi have hypertension and positive urine protein is not necessarily at the time of childbirth will experience the same thing. But this should continue to watch out for preeclampsia can still occur during the puerperium(Saraswati, 2016). Community awareness is focused on the symptoms that are felt during the puerperium period such as dizziness, visual disturbances, heartburn, nausea and vomiting (PRECOG, 2004) The PRECOG guidelines contain early awareness to the community, so that when symptoms appear they can get adequate treatment immediately (PRECOG, 2004). Table 6 illustrates that the detection of pre-eclampsia found in Dander 7 pregnant mothers (3.18) are hypertension with protein + , whereas hypertension without protein urine as much as 9 mothers (4.09\%). While in Kepohbaru Health Center pregnant women preeclampsi have hypertension with urine protein and hypertension without urine protein each $5(50 \%)$. Both did not show any detection of preeclampsia with symptoms. Table 5 shows the underlying risk factors developing into preeclampsia. The biggest factor is diastolic blood pressure $80-89 \mathrm{mmHg}$, that is equal to $68,75 \%$ at Dander Health Center and 50\% at Kepohbaru Health Center. Physiologically, during pregnancy, there will be blood dilution (hemodilution), at the same time the pregnant women is exiting the hormone progesterone which serves musculature reproduction including the blood vessels, so that blood vessels dilate and the presence of hemodilution and blood pressure tends to fall. $80-89 \mathrm{mmHg}$ diastolic blood pressure has been suspected as a risk factor as compared to physiological conditions the mother's pregnancy, the blood pressure has indicated the increased work of the heart that affect the cause of hypertension in pregnancy and 
preeclampsia(Billington, 2010). Based on the analysis of Chi Square test showed sig results were 1.00, so it concluded there was no Differences in recommendations for follow-up of preeclampsection detection results. Based on the results of interviews, at Kepohbaru Puskesmas (control) every preeklamsi conditions according to MAP and ROT guidelines will be referred to hospitals that have adequate service facilities. There is no systematic guidance that describes the treatment of preeclampsia, so that the referral activity is more due to the high level of anxiety in the village midwife to the risk of maternal mortality, because if a mother dies in the birth then the midwife will undergo a series of sufficiently emotionally draining maternal audits, Energy, energy and time.The anxiety that underlies the midwife to refer.This (without clear guidelines) can potentially be uniform in handling, so it is more in the direction of try and error in handling.

\section{Conclusion}

In general, at the two puskesmas, they had similarities in screening for risk factors for preeclampsia. The difference in screening risk factors for Dander Health Center (Intervention) with Kepohbaru Health Center (Control) was that with PRECOG intervention, the risk factors for preeclampsia that were not in the control were BMI, diastolic BP> 80-89 mmHg, and urine protein. Diastolic BP> 80-89mm Hg is a risk factor that develops into preeclampsia, where the factor is ignored in screening preeclampsia risk factors in the control group

Detection of preeclampsia was held at the health center before the intervention Dander and Kepohbaru alike use MAP, ROT, BMI> 29. With the intervention PRECOG, there are differences between PHC Dander detection of pre-eclampsia (PRECOG) with PHC Kepohbaru (control), the control is emphasized In hypertension, urine protein and edema, while on PRECOG is emphasized in conditions of hypertension, urine protein and preeclampsia symptoms. There is a difference on a follow-up screening results in Dander Health Center (PRECOG) with Kepohbaru (control), which is more sensitive PRECOG recommendations and systematic.

\section{References}

[1] McCombs, J. (1992). Treatment of preeclampsia and eclampsia.Clinical pharmacy (Vol. 11). https://doi.org/NBK140561 [bookaccession]

[2] Dinkes Propinsi Jawa Timur (2013). Profil Kes.Prov.JawaTimur 2012. Dinkes Propinsi Jawa Timur.Surabaya.

[3] Billington, \& Stevenson. (2010). Kegawatan dalam kehamilan-persalinan. EGC jakarta.Muhani, N. Preeklamsi berat dan kematian ibu. Jurnal Kesehatan Masyarakat Nasiona Vol. 10 No.2. November 2015

[4] Muhith, A.,et al (2017). nursing service quality model based on the nursing performance, nurse and patient satisfaction. Jurnal Ners Vol.7 No.1. Fakultas Keperawatan Universiatas Airlangga Surabaya.

[5] Muhith, A. (2015). Pendidikan Keperawatan Jiwa (Teori dan Aplikasi). Yogyakarta: Andi.

[6] The Pre-eclampsia Community Guideline Development Group. (2004). PRECOG : The Pre-eclampsia Community Guideline. Retrieved from http://action-on-pre-eclampsia.org.uk/wp-content/uploads/2012/07/PRECOG-CommunityGuideline.pdf

[7] Birnbach. (2009). Anesthesia For Obstetrics dalam : Miller, Ronald P Miller Anesthsia, 7.

[8] Muhith A., dkk (2018). The spatial patten and risk factors of leprosy occurence in barru indonesia. Medicine: Public health, Evironmental and Occupational Health. Indian Journal of Public health Research \& Development. Volume. 9 Number 8. First page 1489-1494. (08 Agustus 2018), ISSN 0978-0245 (print), ISSN 0976-5506 (Electronic). DOI Number: 10.5958/0976-5506.2018,00943.9.

[9] Muhith, A., fardiansyah A., Saputra, M.H., Nurmiyati (2018). Analisis of causes Impacts of Early Marriage on Madurese Sumenep East Java Indonesia. Medicine: Public health, Evironmental and Occupational Health. Indian Journal of Public health Research \& Development. Volume. 9 Number 8. First page 412-416. (08 Agustus 2018), ISSN 0978-0245 (print), ISSN 0976-5506 (Electronic). DOI Number: 10.5958/0976-5506.2018,00944.0.

[10] Muhith, A., Saputra, M.H., fardiansyah A., (2018). Risk factor of rheumatoid arthritis among Eldely in UPT Panti Werdha Mojopahit Mojokerto distric Indonesia. Medicine: Public health, Evironmental and Occupational Health. Indian Journal of Public health Research \& Development.Indian Journal of Public health Research \& Development, Volume. 9 Number, 6 June 2018, ISSN 0978-0245 (print), ISSN 0976-5506 (Electronic). DOI number: 10.5958/0976-5506.2018.00589.2. 